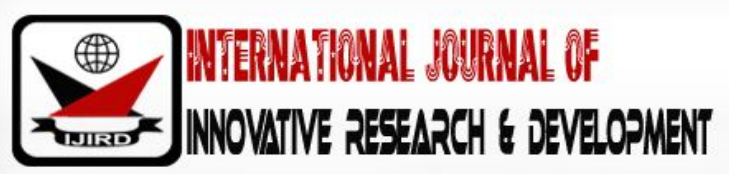

ISSN 2278 - 0211 (Online)

\section{Implementation of Minimum Wage and Social Inequality Gap among Workers' in Imo State Civil Service, Nigeria}

\author{
Dr. Uchechukwu Anthony Nwobi \\ Post-Doctoral Fellow, University of Nigeria, Nsukka, Nigeria
}

Abstract:

Civil servants' in Ministries of Justice, Health and Livestock in Ministry of Agriculture earn higher wage than workers' in other ministries just like workers are paid stipends compared to politicians. That led to increased disparity between the low-income earners and the top salary earners. The inequality caused retarded growth and development of the workers' which accounted for a huge margin in the allocation of benefits and allowances to employees of different strata. It was on that premise that the paper sought to assess the effects of implementation of minimum wage on social inequality gap among workers'. The study was a survey design. Proportionate sampling technique was used. Interview and questionnaire were used to generate primary data to compliment the secondary data obtained from books, journals, newspapers, magazines. The paper recommends harmonized minimum wage, workers' access to reasonable purchasing power that meets with competing demands of the society.

Keywords: Minimum wage, implementation, social inequality, workers, civil service

\section{Introduction}

The aim of government in setting a minimum wage is to raise wages of workers whose wage are relatively low so as to bridge the inequality gap among workers. Although the goals are widely accepted as proper, there is great disagreement as to whether the minimum wage is effective in attaining its goals (Akpansung, 2014). Unfortunately, minimum wage legislation always ended up increasing the disparity between the low-income earners and the top salary earners.

In the light of the above, the rising inequality and the challenges it posed on civil servants in the State became a great concern because it led to retarded growth and development of the workers which created a huge margin in the allocation of benefits and allowances to employees of different strata. It was worthy of note that in the State, civil servants in Ministries of Justice, Health and Livestock in Ministry of Agriculture earn higher wage than workers' in other ministries. Another remarkable challenge was evident in the lives of civil servants who were paid stipends compared to what politicians took home AhiumaYoung, (2011). That incubated wide socio-economic gap between the rich and poor, the different ministries which led to unequal access to assets, income and expenditure on food, hospital bills, housing, transport cost, utilities (Asodike and Atuwokiki, 2012).

That unequal access on expenditure was also reflected on affordability of food, hospital bills, housing, transport cost, utilities. In addition, it created widespread disaffection which affected economic performance and increased feelings of unfairness because of unequal opportunity that was created amongst the workers in different ministries (Stanlake and Grant, 1999).Given the available resources and level of development, the State is supposed to be paying the highest minimum wage round the world but the reverse is the case. Thus, the need to address the huge inequality gap among the civil servants in the State arose(Emejuiwo, 2017).It was on that premise, that the study sought to assess the effects of the implementation of minimum wage on social inequality gap among workers' in Imo state civil service, Nigeria.

\section{Conceptual Clarifications}

\subsection{Minimum Wage}

The term minimum wage is relative in nature. Rosen (2008) defined minimum wage as the rate of remuneration fixed either by a collective bargaining agreement or by government enactment as the lowest wage to be paid to specified class of employees. Employees have the right to demand an amount of money above the established minimum wage. Similarly, International Labour Office (2009: 2) defined minimum wage as The lowest level of remuneration permitted.... which in each country has the force of law and which is enforceable under threat of penal or other appropriate sanctions. Minimum wage fixed by collective agreements made binding by public authorities is included. 
In the light of the above, minimum wages are universal policy instrument legally permitted in an organisation to meet the needs of workers and alleviate poverty. Such needs are food, housing, clothing, healthcare and utilities. Furthermore, Eme (2010) explain that minimum wage implies the lowest level of wage legally permitted in an industry, or in a government or organization. The fundamental goal in establishing minimum wage is to assure earners a standard of living above the lowest permitted by health and decency.

In a similar vein, despite the growth in the Nigerian economy which is being driven by non-oil sectors, inequality has continued to rise. Furthermore, one of the major challenges facing the economy is the rising inequality, as only ten percent of the population enjoys the benefits of economic growth. The other area of concern is that growth in Nigeria is unequal. Inequality is high and rising. Inequality is highly concentrated in certain regions of the economy. As such, something has to be done to pay attention on regional disparity Okonjo-Iwuala in Idike, A (2014).

\subsection{Social Inequality}

Is the expression of lack of access to education, housing, health care, status, employment opportunities among others. It could also connote the exclusion of workers from equal participation in what civil servants and the society perceive as being valuable, essential and socially desirable (Ubong, 2013). Inequality refers to the gap between individuals and groups within a society but can also refer to inequality among nations. Certain reasons give rise to inequality. They include inequality in wages and salaries, wealth concentration in the hands of a few individuals or institutions (Growing gap between the rich and poor, 2017). In Nigeria, uneven distribution of income (wages and salaries, allowances etc) has always been an issue of serious concern in the State. Interestingly, when workers' do not possess the same level of material wealth or overall living economic conditions, it becomes inequality of outcome. That was reflected in standards of living like inequality in income/ wealth, education, health and nutrition. In the same perspective, economic inequality connotes how economic variables are shared among workers' or individuals in a system Afonso, Lafleur and Alarcon, (2015). In a nut shell, inequality from the above views is encapsulated as lack of equal access to material well-being and income by workers' or an uneven distribution of allocations.

\subsection{Minimum Wage and Inequality}

It is interesting to note that the huge gap between the rich and poor in Nigeria is anchored on inequality in income distribution of workers. The payment of N18, 000 minimum wages (poverty wage) and the disparity between the rich and poor, the workers of different strata make Nigeria non-existent. In a similar vein, despite the growth in the Nigerian economy which is being driven by non-oil sectors, inequality has continued to rise. Furthermore, one of the major challenges facing the economy is rising inequality, as only ten percent of the population enjoys the benefits of economic growth. The other area of concern is that growth in Nigeria is unequal. Inequality is high and rising. Inequality is highly concentrated in certain regions of the economy. As such, something has to be done to pay attention on regional disparity Okonjo-Iwuala in Idike, A (2014).

In other words, one of the implications of income inequality is that it concentrates the power to take political decisions in the hands of a few individual. That could ignite suboptimal use of human resources and political instability. Inequality increases the influence of the rich and decreases the income of the poor. Although certain level of inequality might not be a challenge if it meets some needs such as provision of incentives for people to excel, compete, save and invest geared towards attaining stability in life. Inequality can also influence growth via provision of incentives for innovation and entrepreneurship. That would allow some individual an opportunity to accumulate the minimum needed to start businesses and get a good education Dabla-norris, Kochhar, Suphaphiphat, Ricka and Tsounta (2015).

That was also reflected in the summation that the wealth of Nigeria's richest five could end poverty in the nation. It also brought to lime light the fact that the nation's resources are concentrated in the hands of a few individual. That's the picture of the existing gap in Nigeria Runse we, (2017). To wriggle out of the challenge, minimum wage was considered by many to be a major policy tool to reduce inequality yet that objective has never been the achieved. In America for instance, if an average full-time employee works 1,700 hours per year, then moving from $\$ 7.25$ an hour to $\$ 9$ an hour produces only about $\$ 2,975$ in additional annual earnings. That slight increase is important but would be at best a marginal solution to inequality. In situations where minimum wage has no unintended side effects, it appears to only marginally reduce inequality (Makridis, 2016). In another dimension, minimum wage supports greater wage growth at the bottom and also benefits middle class earners (Mishel, 2014).

Again, the simple fact that the self-professed richest black person in the world is from the same nation where $54 \%$ of the population are living below the national poverty line, confirmed that there is severely unequal distribution of wealth. Statistical data also has it that the Gini Coefficient for income inequality in Nigeria gives a 0 to a perfectly equal distribution where Nigeria gets 43.7 (0.437) in 2003 on that scale which makes it more unequal than Ghana, Senegal, Tanzania and Egypt etc. Inequality of opportunity was also recorded in education, healthcare, justice, security, capital and political representation. The rich could afford better access to healthcare, education, financial market, higher levels of justice and security, more political access and participation both within and in Diaspora. One implication of social inequality is that in an unequal society, people are less likely to trust themselves Chukwueke, E. (2010). Suffice to say that inequality is inherent in the State such that the previous minimum wage increases could not close the existing gap. 


\section{Methodology}

The study was a survey design. The total population of the study was 6370 but the study made use of $10 \%$ as the sample size. The population was divided proportionately among the ministries using proportionate sampling technique. In gathering data, a face-to-face interview and questionnaire were used to generate primary data to compliment the secondary data obtained from books, journals, newspaper, magazines etc. A pilot survey was used to determine the reliability of the instrument and Pearson Product Moment Coefficient of Correlation was used to compute the coefficient from the two results which gave 0.69 . The documents were face and content validated by experts. The data was presented in tables and a five-point Likert scale was used. The data collected were analyzed using the mean of the responses.

\subsection{Theoretical Framework}

System theory was adopted as the theoretical umbrella for this discourse. It is relevant to this study because is found in every sphere of learning. In addition, is a trans-disciplinary framework for the explanation of relationships between the representatives of government, employers and employees on issues of common interest relating to social and economic policies within the environment it represents (Fajana and Shadare, 2012). See diagram below.

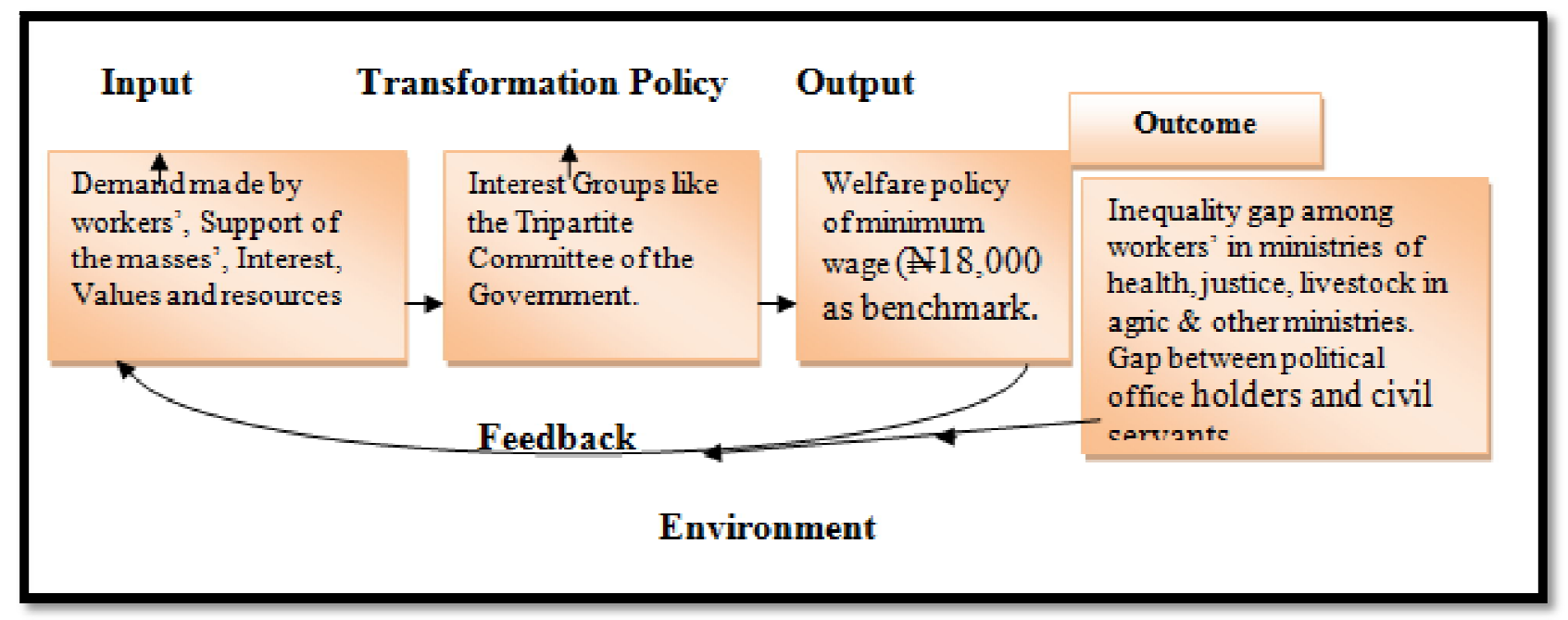

Figure 1: A Diagram Showing the Input-Output Transformation of System Theory to Implementation of Minimum Wage and Social Inequality Gap among Workers' Adapted from Izueke, E (2014), Theoretical Framework of Analyses in Public Administration, in 0, Ikeanyibe and P. Mbah (Eds), an Anthology of Theories for Social Research, (159-183), Enugu: University of Nigeria Press Ltd

Civil servants made a demand on the Government which represents the input. The demand was sent into the system where it was transformed through negotiation (collective bargaining) by the stakeholders. The output became what the stakeholders arrived at from the bargaining process. That was the implementation of $\$ 18,000$ as a benchmark. The outcome referred to the effect it had on the workers' (masses) who made the demand on the system. Such as increased social inequality gap among workers' in ministries of health, justice, livestock in ministry of agriculture and other ministries. The effects were sent through a feedback mechanism to those who made the demand. The dissatisfaction of the masses would warrant resending their input into the system for reprocessing until their needs are met.

\section{Data Presentation and Analysis}

The data showed that out of 637 questionnaires administered, 627 copies (\%) were returned while 10 (\%) were missing.Out of 627 questionnaires returned from the respondents, 336 (54\%) were male while 291 (46\%) were female. Age showed that out of 627 questionnaires returned, 60 (9\%) were under 20 years of age, 199 (32\%) were between 21- 30 years, 213 (34\%) were between 31-40 years, 105 (17\%) were between 41-50 years, 50 (8\%) were between 51-60 years and nonabove 60 years. Marital status: 390 (62\%) were married and 237(38\%) were single. Categories of staff showed that out of the 627-questionnaire returned, 162 (26\%) were management staff, $215(60 \%)$ were senior staff and 250 (40\%) were junior staff. 


\begin{tabular}{|c|c|c|c|c|c|c|c|c|}
\hline $\mathbf{S} / \mathbf{N}$ & Items & $\begin{array}{c}\text { SA } \\
5\end{array}$ & $\begin{array}{l}\text { A } \\
4\end{array}$ & $\begin{array}{c}\text { UD } \\
3\end{array}$ & $\begin{array}{l}\mathbf{D} \\
\mathbf{2} \\
\end{array}$ & $\begin{array}{c}\text { SD } \\
1\end{array}$ & Mean & Decision \\
\hline 1 & Food Items & $\begin{array}{c}31 \\
(10 \%)\end{array}$ & $\begin{array}{c}84 \\
(28 \%)\end{array}$ & $\begin{array}{c}10 \\
(3 \%)\end{array}$ & $\begin{array}{c}139 \\
(47 \%)\end{array}$ & $\begin{array}{c}35 \\
(12 \%)\end{array}$ & 2.78 & Rejected \\
\hline 2 & Hospital Bill & $\begin{array}{c}16 \\
(5 \%)\end{array}$ & $\begin{array}{c}26 \\
(9 \%)\end{array}$ & $\begin{array}{c}17 \\
(5 \%)\end{array}$ & $\begin{array}{c}193 \\
(65 \%)\end{array}$ & $\begin{array}{c}47 \\
(16 \%)\end{array}$ & 2.13 & Rejected \\
\hline 3 & Water Bill & $\begin{array}{c}130 \\
(44 \%)\end{array}$ & $\begin{array}{c}91 \\
(30 \%)\end{array}$ & $\begin{array}{c}28 \\
(9 \%)\end{array}$ & $\begin{array}{c}27 \\
(9 \%)\end{array}$ & $\begin{array}{c}23 \\
(8 \%)\end{array}$ & 3.92 & Accepted \\
\hline 4 & $\begin{array}{l}\text { School } \\
\text { Fees }\end{array}$ & $\begin{array}{c}55 \\
(18 \%)\end{array}$ & $\begin{array}{c}200 \\
(67 \%)\end{array}$ & $\begin{array}{c}1 \\
(0.3 \%)\end{array}$ & $\begin{array}{c}32 \\
(10.7 \%)\end{array}$ & $\begin{array}{c}11 \\
(4 \%)\end{array}$ & 3.85 & Accepted \\
\hline 5 & Transport & $\begin{array}{c}23 \\
(8 \%)\end{array}$ & $\begin{array}{c}55 \\
(18 \%)\end{array}$ & $\begin{array}{c}15 \\
(5 \%)\end{array}$ & $\begin{array}{c}165 \\
(55 \%)\end{array}$ & $\begin{array}{c}41 \\
(14 \%)\end{array}$ & 2.37 & Rejected \\
\hline 6 & House Rent & $\begin{array}{c}16 \\
(5 \%)\end{array}$ & $\begin{array}{c}31 \\
(10 \%)\end{array}$ & $\begin{array}{c}17 \\
(6 \%)\end{array}$ & $\begin{array}{c}154 \\
(52 \%)\end{array}$ & $\begin{array}{c}81 \\
(27 \%)\end{array}$ & 2.15 & Rejected \\
\hline 7 & Electricity Bill & $\begin{array}{c}16 \\
(5 \%)\end{array}$ & $\begin{array}{c}37 \\
(13 \%)\end{array}$ & $\begin{array}{c}22 \\
(7 \%)\end{array}$ & $\begin{array}{c}167 \\
(56 \%)\end{array}$ & $\begin{array}{c}57 \\
(19 \%)\end{array}$ & 2.29 & Rejected \\
\hline 8 & Clothes & $\begin{array}{c}48 \\
(16 \%)\end{array}$ & $\begin{array}{c}190 \\
(64 \%)\end{array}$ & $\begin{array}{c}18 \\
(6 \%)\end{array}$ & $\begin{array}{c}28 \\
(9 \%)\end{array}$ & $\begin{array}{c}15 \\
(5 \%)\end{array}$ & 3.76 & Accepted \\
\hline 9 & $\begin{array}{l}\text { Entertainment } \\
\text { Cost }\end{array}$ & $\begin{array}{c}14 \\
(5 \%)\end{array}$ & $\begin{array}{c}44 \\
(15 \%)\end{array}$ & $\begin{array}{c}22 \\
(7 \%)\end{array}$ & $\begin{array}{c}178 \\
(59 \%)\end{array}$ & $\begin{array}{c}41 \\
(14 \%)\end{array}$ & 2.37 & Rejected \\
\hline 10 & Kerosene & $\begin{array}{c}17 \\
(6 \%)\end{array}$ & $\begin{array}{c}36 \\
(12 \%)\end{array}$ & $\begin{array}{c}19 \\
(6 \%)\end{array}$ & $\begin{array}{c}173 \\
(58 \%)\end{array}$ & $\begin{array}{c}54 \\
(18 \%)\end{array}$ & 2.29 & Rejected \\
\hline 11 & $\begin{array}{l}\text { Soaps and } \\
\text { Detergents }\end{array}$ & $\begin{array}{c}26 \\
(9 \%)\end{array}$ & $\begin{array}{c}121 \\
(40 \%)\end{array}$ & $\begin{array}{c}12 \\
(4 \%)\end{array}$ & $\begin{array}{c}114 \\
(38 \%)\end{array}$ & $\begin{array}{c}26 \\
(9 \%)\end{array}$ & 3.02 & Accepted \\
\hline & Total & 392 & 915 & 181 & 1216 & 431 & 30.93 & \\
\hline & Grand Mean & & & & & & 2.81 & Rejected \\
\hline
\end{tabular}

Table 1: Percentage, Decision and Mean Scores of Respondents on Whether

Implementation of Minimum Wage Has Helped In Bridging the

Differences in Spending among Workers'

Source: Author's Field Survey (2018)

$\operatorname{Mean}\left(\mathrm{X} \overline{)}=\frac{\sum f x}{N}\right.$

Data on Table 1: showed that items 3, 4, 8 and 11 had mean scores above the criterion mean of 3.0. That indicated acceptance. The other items 1, 2, 5, 6, 7, 9 and 10 had mean scores below the criterion mean of 3.0. They were therefore rejected. In general, a greater number of the mean of the items were rejected. We therefore conclude that the implementation of minimum wage had not helped in bridging social inequality gap among the civil servants in Imo State civil service.

\subsection{Effects of the Implementation of Minimum Wage on Social Inequality Gap among Workers' in Imo State Civil Service}

Before May 1st 2000, the gap between the lowest paid Federal civil servant and the highest paid was N90, 000 per annum. With the new minimum wage implementation, the gap worsened to over N200, 000 per annum. Thus, the agitation for minimum wage increase which should have addressed the gap (make for equitable distribution of income) failed in one of its objectives. Nigerian Labour Congress ended up working for the rich more than the poor. In other words, minimum wage was a pyrrhic victory (Sobowale, 2000). In the same direction, minimum wage implementation did not bridge the gap because civil servants operated in the same market. If incremental benefits were higher for one category of workers, the gap would definitely continue unabated but if the increase was the same at all levels, the existing gap would have closed up (On werre, J. Personal communication, 2018). Towing the same line of argument, civil servants come from different economic and social background. They grew in different neighborhood, attended different schools and faced different economic and social difficulties, attended the same market yet earned differently. The multiplier effect fell on the purchase of basic needs like food, housing, transportation; utilities etc. A worker with a higher salary of N100.000 per month in Health Ministry and another N50, 000 salaries per month in Ministry of Youth and Sports could not demand the same quantity of garri at N50 per cup. The two have a family of four each; and it was discovered that, the worker with a higher income took better care of his family in the area of feeding than a worker with a lower income. That showed the existence of gap among the workers (Pennington, 1999). There was also a revelation that a civil servant on grade level 1 step 1 took a higher salary than someone on grade level 2 step 1and many others like that. That showed another gap among the workers as supported by (Agorua, C. Personal communication, 2018).

As the new payment of minimum wage took effect, it was seen as over 100\% increase. A Director in the State service on grade

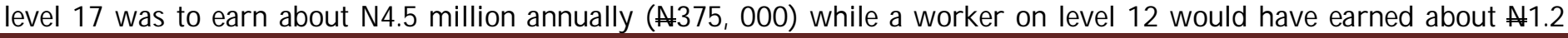


million annually ( 1100.00 monthly). Ironically, what was on the Imo State salary table based on $\$ 20,000$ for a Director on grade level 17 is \$85,079.13 per month and \$1,020,949.55 annually, while a worker on level 12 earned $\$ 40$, 504.02 per month and 486,048.25 annually. From the explanation, it became obvious that the minimum wage, instead of closing the existing gap, ended up making it wider than necessary (Omar, 2011). Lawyers earned hazard allowance while others do not. All civil servants faced the same hazard. Many had died in the process of discharging their duties as civil servants. That was occupational hazard but they were not paid hazard allowance. Lawyers take home hazard allowance because they go to court. That created a gap between the workers. The market forces began to bite harder on the low earners because they could not meet their basic needs as much as the high-income earners (Odulukwe, 2014). In a similar view, employees of the Ministries of health, justice and Livestock under ministry of Agriculture etc. took more even though they saved life. A level 8 officer in the Ministry of Health/ Livestock under ministry of Agriculture took home about \$100, 000 per month while an officer of the same grade level in other Ministries (department) earned about \$50, 000. The margin was so wide that it became so glaring that the implementation of minimum wage widened inequality among civil servants (Chuks, O. L. Personal Communication, 2018). The inequality was made more conspicuous in the table as shown below .

\begin{tabular}{|c|c|c|c|c|c|c|c|}
\hline Grade Level/ step & MGBS & MGBS & & MGBS & & MGBS & \\
\hline & $\begin{array}{c}\text { Other } \\
\text { Ministries } \\
\text { (13 in } \\
\text { Number) }\end{array}$ & $\begin{array}{l}\text { Ministry } \\
\text { of } \\
\text { Health }\end{array}$ & $\begin{array}{c}\text { Disparity } \\
\text { b/ w Health } \\
\text { \&Other } \\
\text { Ministries }\end{array}$ & $\begin{array}{l}\text { Ministry of } \\
\text { Justice }\end{array}$ & $\begin{array}{c}\text { Disparity } \\
\text { b/ w Justice } \\
\text { \&Other } \\
\text { Ministries }\end{array}$ & $\begin{array}{l}\text { Livestock in } \\
\text { Ministry of } \\
\text { Agriculture }\end{array}$ & $\begin{array}{c}\text { Disparity b/ w } \\
\text { Livestock(Agr } \\
\text { ic) \&Other } \\
\text { Ministries }\end{array}$ \\
\hline GL 1/ 1-15 & \begin{tabular}{|c|}
$20,000.00-$ \\
$22,617.12$ \\
\end{tabular} & $\begin{array}{l}33387- \\
44765 \\
\end{array}$ & $\begin{array}{c}13387- \\
22147.88\end{array}$ & $\begin{array}{c}45,149.94- \\
50,159.88\end{array}$ & $\begin{array}{c}25,149.94- \\
27,542.76 \\
\end{array}$ & $\begin{array}{l}31176- \\
41639\end{array}$ & $\begin{array}{c}11176- \\
19021.88\end{array}$ \\
\hline GL 2/ 1-15 & $\begin{array}{c}20,374.54- \\
23,754.75\end{array}$ & $\begin{array}{l}33781- \\
37766\end{array}$ & $\begin{array}{l}13406.46- \\
14011.25\end{array}$ & $\begin{array}{l}45857.84- \\
52,337.63\end{array}$ & $\begin{array}{l}25483.3- \\
28582.88\end{array}$ & $\begin{array}{l}31539- \\
44399\end{array}$ & $\begin{array}{l}11164.46- \\
20644.25\end{array}$ \\
\hline GL 3/ 1-15 & $\begin{array}{c}20,677.02- \\
24,921.65 \\
\end{array}$ & $\begin{array}{l}35176- \\
52029 \\
\end{array}$ & $\begin{array}{l}14498.98- \\
27107.35 \\
\end{array}$ & $\begin{array}{c}46,445-54 \\
571.41\end{array}$ & $\begin{array}{l}25767.98- \\
29649.76 \\
\end{array}$ & $\begin{array}{l}32821- \\
48232 \\
\end{array}$ & $\begin{array}{l}12143.98- \\
23310.35\end{array}$ \\
\hline GL 4/ 1-15 & $\begin{array}{l}21,163.65- \\
27,027.70\end{array}$ & $\begin{array}{l}39269- \\
50794\end{array}$ & $\begin{array}{c}18105.35- \\
23766.3\end{array}$ & $\begin{array}{l}47,377.47- \\
58,632.92\end{array}$ & $\begin{array}{l}26213.82- \\
31605.22\end{array}$ & $\begin{array}{l}36584- \\
54540\end{array}$ & $\begin{array}{c}15420.35- \\
27512.3\end{array}$ \\
\hline GL 5/ 1-15 & $\begin{array}{c}22,552.39- \\
29,407.25 \\
\end{array}$ & $\begin{array}{l}46909- \\
70702\end{array}$ & $\begin{array}{l}24356.61- \\
41294.75\end{array}$ & $\begin{array}{c}50,112.57- \\
63,158.13\end{array}$ & $\begin{array}{l}27560.18- \\
33750.88\end{array}$ & $\begin{array}{l}43611- \\
64410\end{array}$ & $\begin{array}{l}21058.61- \\
35002.75\end{array}$ \\
\hline GL 6/ & $\begin{array}{l}25,359.32- \\
33,567.07\end{array}$ & $\begin{array}{l}70636- \\
104964\end{array}$ & $\begin{array}{l}45276.68- \\
71396.93\end{array}$ & $\begin{array}{c}55,314.82- \\
71,118.50\end{array}$ & $\begin{array}{l}29955.5- \\
37551.43\end{array}$ & $\begin{array}{l}66212- \\
98182\end{array}$ & $\begin{array}{c}408 \mathrm{y} 52.68- \\
64614.93\end{array}$ \\
\hline GL 7/ 1-15 & $\begin{array}{l}37,099.25- \\
47,337.34 \\
\end{array}$ & $\begin{array}{l}179489- \\
263956\end{array}$ & $\begin{array}{l}142389.75- \\
216618.66\end{array}$ & $\begin{array}{c}80,454.30- \\
99,760.40\end{array}$ & $\begin{array}{l}43355.05- \\
52423.06\end{array}$ & $\begin{array}{l}98622- \\
143679 \\
\end{array}$ & $\begin{array}{c}61522.75- \\
96341.66\end{array}$ \\
\hline GL 8/ 1-15 & $\begin{array}{c}43,999.32- \\
55,410.98 \\
\end{array}$ & $\begin{array}{c}209253- \\
309002\end{array}$ & $\begin{array}{l}165253.68- \\
253591.02\end{array}$ & $\begin{array}{l}92,962.13- \\
114,984.96 \\
\end{array}$ & $\begin{array}{l}48962.81- \\
59573.98 \\
\end{array}$ & $\begin{array}{l}13898- \\
166945 \\
\end{array}$ & $\begin{array}{l}69898.68- \\
111534.02\end{array}$ \\
\hline GL 9/1-15 & \begin{tabular}{|c|}
$48,669.18-$ \\
$62,262.04$ \\
\end{tabular} & $\begin{array}{l}245964- \\
355377 \\
\end{array}$ & $\begin{array}{l}197264.82- \\
293114.96 \\
\end{array}$ & $\begin{array}{l}100,298.75- \\
127,904.06 \\
\end{array}$ & $\begin{array}{l}51629.57- \\
65642.02 \\
\end{array}$ & $\begin{array}{l}133827- \\
191825 \\
\end{array}$ & $\begin{array}{c}85157.82- \\
129562.196 \\
\end{array}$ \\
\hline GL10/ 1-15 & $\begin{array}{c}54,036 . .41- \\
68,988.66\end{array}$ & $\begin{array}{l}287644- \\
382288\end{array}$ & $\begin{array}{l}233607.59- \\
313299.34\end{array}$ & $\begin{array}{l}110,219.69- \\
140,588.58\end{array}$ & $\begin{array}{l}56183.28- \\
71599.92-\end{array}$ & $\begin{array}{l}157846- \\
197667\end{array}$ & $\begin{array}{l}103809.59- \\
128678.34\end{array}$ \\
\hline GL12/ 1-11 & $\begin{array}{c}60,949.27- \\
77,312.73\end{array}$ & $\begin{array}{c}381932- \\
504105\end{array}$ & $\begin{array}{l}320982.73- \\
426792.35\end{array}$ & $\begin{array}{l}117,865.52- \\
151,107.47\end{array}$ & $\begin{array}{l}56916.25- \\
73794.74\end{array}$ & $\begin{array}{l}218663- \\
277833\end{array}$ & $\begin{array}{l}157713.73- \\
200520.27\end{array}$ \\
\hline GL13/1-9 & $\begin{array}{l}64,985.45- \\
84,207.34\end{array}$ & $\begin{array}{l}570018- \\
733226\end{array}$ & $\begin{array}{l}505032.55- \\
649018.66\end{array}$ & $\begin{array}{c}129,034.88- \\
164,041.32\end{array}$ & $\begin{array}{c}64049.43- \\
79833.98\end{array}$ & $\begin{array}{l}273352-- \\
339708\end{array}$ & $\begin{array}{l}208366.55- \\
255500.66\end{array}$ \\
\hline GL14/ 1-9 & \begin{tabular}{|c|}
$71,862.24-$ \\
$92,555.78$ \\
\end{tabular} & $\begin{array}{c}677959- \\
872780 \\
\end{array}$ & $\begin{array}{c}606096.76- \\
780224.22 \\
\end{array}$ & $\begin{array}{c}143,805.20- \\
180,844.83 \\
\end{array}$ & $\begin{array}{c}71942.96- \\
88289.05 \\
\end{array}$ & $\begin{array}{l}333864- \\
412640 \\
\end{array}$ & $\begin{array}{c}262001.76- \\
320084.22 \\
\end{array}$ \\
\hline GL15/1-9 & \begin{tabular}{|l|}
$103,974.93-$ \\
$126,118.14$ \\
\end{tabular} & $\begin{array}{l}811708- \\
1034499\end{array}$ & $\begin{array}{l}\text { 707733.07- } \\
908380.86\end{array}$ & $\begin{array}{l}239,054.40- \\
286,120.56\end{array}$ & $\begin{array}{l}135079.47- \\
160002.42\end{array}$ & $\begin{array}{l}409250- \\
499743 \\
\end{array}$ & $\begin{array}{c}305275.07- \\
373624.86\end{array}$ \\
\hline GL16/1-9 & \begin{tabular}{|l|}
$144,805.87-$ \\
$171,635.63$
\end{tabular} & - & - & $\begin{array}{l}340,948.73- \\
398,089.15\end{array}$ & $\begin{array}{l}196142.86- \\
226453.52\end{array}$ & - & - \\
\hline GL17/ 1-9 & \begin{tabular}{|l}
$162,037.26-$ \\
$192,528.62$
\end{tabular} & - & - & $\begin{array}{l}428,602.22- \\
502,110.62\end{array}$ & $\begin{array}{c}266564.96- \\
309582\end{array}$ & - & - \\
\hline
\end{tabular}

Table 3: Summary of the Disparity on Implementation of Minimum Wage among the Ministries in Imo State Civil Service Based On 20, 000Source: Adapted from Government of Imo State. (2011),

New Minimum Wage For Imo State Public Servants' Establishment Circular No 1/2011,

Owerri: Office of the Head of Service.Updated by the Author (2018)

In the Ministry of Justice, there are medical, hazard, uniform, outfit, furniture and leave bonus allowances which were not reflected in other ministries. Despite that, other allowances that all the ministries earn in common, those of ministries of justice, health and Livestock under ministry of Agriculture are higher Government of Imo State (2012). A grade level 08 in ministries of health, justice, agric take home $\$ 100,000$ per month while the same level 08 in other ministries earn N50, 000 (Chuks, O. L. Personal Communication, 2018). This situation forced workers to seek for posting to the ministries that pay higher wage (Agorua, C. Personal Communication, 2018). 
The disparity in minimum wage between Livestock in Ministry of Agriculture, Ministries of Health and Justice ranged from $\$ 11,176, \$ 13,387$ and $\$ 25,149.94$ respectively. That generated widespread disaffection which affected economic performance. It incubated feelings of unfairness because of unequal opportunity that was erected. The higher income earner (wealthy) could buy superior education and training for their children and there was no doubt that the possession of wealth conferred on the higher earners certain social advantages (Stanlake and Grant, 1999). It affected the children in the way they felt and related with their peers, which affected the way they took up opportunities and their society. Unfortunately, the minimum wage did not improve inequality of education (Adegoke, 2013). In Imo state, because wages have not kept up with inflation over a long period, the purchasing power of most consumers remained declined drastically (Thomas, 2000).

In the same perspective, the gulf between the rich and the poor grew wider every day in Imo State because of wage discrimination. The worker was perpetually conditioned in wage situation that was only enough to multiply his/her race. While political office holders continued to line their pockets with fat wages, that were generated from the sweat of the workers, the average Imo State/ Nigerian worker could hardly feed his/ her family. A sizeable proportion of Imo State workers received starvation wage, and over 75 per cent of them lived in abject poverty. Hundreds of thousands of working classes lived in rotten tenements and could not access or afford medical services. It was increasingly difficult for workers to send their children to school. The new height of hardship among workers in Imo State was responsible for the waves of industrial disputes in recent times (Agba, Ogaboh, and Ushie, 2013).

Wage differential between hospital staff and political office holders accounted for strike actions in Imo State (Nigerian) hospitals. The disproportionate increase in the wages of political office holders as against civil servants informed all types of industrial actions. It was observed that between 2006 and 2007, political office holders received over 800 percent wage increase against 40 percent for public workers. The "starvation wages" given to civil servants made it increasingly difficult for the average Imo State worker to survive on monthly remuneration. The workers situation was further aggravated in the face of increasing inflation of about 14 percent. Suffice to say that minimum wage implementation did not bridge the social inequality among workers in Imo State civil service (Agorua, C. Personal Communication, 2018).

\begin{tabular}{|c|c|c|}
\hline Governor & $\mathrm{N1,200,000.00}$ & \\
\hline Deputy Governor & N1000000.00 & \\
\hline Secretary to the State Government & N700,000.00 & \\
\hline Speaker of the State House of Assembly & $\$ 500,000.00$ & \\
\hline & & No of Personnel \\
\hline Commissioner & $\$ 500,325$ per person & 18 \\
\hline Senior Special Asst & N153,000.00 per person & 34 \\
\hline Senior Assistants & N141,000.00 per person & 22 \\
\hline Personal Assistants & \$138,000.00 per person & 28 \\
\hline Chief of Staff & N368,058.6 per person & 3 \\
\hline Chief Press Secretary & $\mathrm{N} 265,022.00$ per person & 5 \\
\hline Legislative Aides & $\$ 58,000.00$ per person & 54 \\
\hline House of Assembly & $\mathrm{N} 350,000.00$ per person & 30 \\
\hline Special Advisers & N450,175.8p & 21 \\
\hline
\end{tabular}

Table 4: Breakdown of Basic Salaries of Government Officials in the State

Source:Agba, M. Achimugu, C and Agboni, U. (2012). Reward System in the Nigerian

Political and Public Sector: the Call for a Paradigm Shift in the 21st Century, International Journal of Learning \& Development, 2, Pp. 79-85

In view of the above table, a few politicians in power fed fat on the masses at the expense of the development of the State. It also justified the call by workers for a paradigm shift to review downward the wages and allowances of politicians to reflect the prevailing socio-economic reality of a State of about 165 million people and yet less than 10 million could boast of having a decent living. To say the least, politicians at the State level are the highest paid public office holders; consequently, politics in Nigeria became corrupt and wrongly perceived as a commercial and business venture where millions of naira was invested in the electoral process and billions of naira reaped as profit (Agba, Coker and Agba, 2010). In confirming the above view, the National Assembly members and 469 Senators and House of Representatives members earn salaries and allowances that can pay the minimum wage of 1000 workers. Nigerian law makers are the highest paid in the world with an annual salary of 189,500 dollars ( $130.6 \mathrm{~m}$ ) each which excludes allowances. Emejuiwe2, (2018)

The habit of eating food outside one's matrimonial home was more pronounced among senior civil servants. This could be explained in part, by the fact that senior civil servants were likely to eat at more expensive restaurants than the junior civil servants. Also, senior civil servants ate more outside than the junior workers (Cage, 1989).

The share for rented dwelling place was higher for junior civil servants. On the other hand, owned dwelling places were higher for senior civil servants than junior civil servants. Cost of accommodation for one room was N5000 per month, and three bed room flat 40, 000 per month (Ayoka, I. Personal Communication, 2018). Senior civil servants spent higher on 
fees and admissions to sporting events and clubs than the junior civil servants. These include club membership dues which were generally very expensive. Cost of education, cash contribution and monies allotted to retirement funds, pensions and social security were significantly higher for senior civil servants than junior civil servants. These widened the gap. High inequality reduced the pool of people with access to the resources-such as land or education--needed to unleash their full productive potential. Thus, the State deprived itself of the contributions the low-income earners could have made to its economic and social development. It threatened the State's political stability because more people were dissatisfied with their economic status, which made it harder to reach political consensus among population groups with higher and lower incomes. As such, political instability increased the risks of investing in the State and so significantly undermined its development potential. It limited the use of important market instruments such as changes in prices and fines. For example, higher rates for electricity and hot water might promote energy efficiency, but in the face of serious inequality, government's introduction of slightly higher rates risk caused extreme deprivation among the poorest citizens (Onwerre,J. Personal Communication, 2018). On transport, the average number of cars owned by senior and junior civil servants varied. Initially, a senior civil servant who owned a car could afford to maintain it easily than it is presently given the minimum wage increases. The reason for low expenditure on transport was that a large proportion of workers lived in urban areas and therefore had public transport at their disposal for commuting needs. Senior civil servants used official cars/vehicles. Some transportation expenses were likely reimbursed to senior civil servants unlike the junior civil servants. Unfortunately, the 2011 Minimum Wage Act eroded all the benefits and widened the gap among the workers in Imo State (Umunakwe, S. Personal Communication, 2018).

\section{Summary}

The study was an effort to explore minimum wage implementation and social inequality gap among workers' in Imo State Civil Service to assess the effects of implementation of minimum wage on social inequality gap among workers'. The study was a survey design. In gathering data, the primary and secondary sources of data were used. The data was presented in tables and a five-point Likert scale was used. The data collected were analyzed using the mean of the responses.

Implementation of minimum wage could not bridge social inequality gap among workers'.The gap between the ministries, political office holders and civil servants did not allow a significant impact of the wage to manifest conspicuously. Workers took home a paltry sum while politicians stashed away the nation's resources. Some ministries were paid better allowances than other. That generated widespread disaffection which affected economic performance. In order to bridge the gap, there has to be a uniform salary for all the ministries and political office holders because the market forces are the same everywhere in the nation.

\section{Recommendations}

- To reduce inequality, minimum wage should be harmonized so that when a worker moves from one grade level to another, there would be tangible increase. This could be achieved through the establishment of special courts for trying cases as a means of speeding up the trial of cases and reducing the effect of massive noncompliance on implementation of minimum wage. The Ministry of Labour and Productivity should champion the course.

- Workers should be granted access to reasonable purchasing power that meets with competing demands of the society. To achieve this, there must be real cost computation. Consideration must be given to the market cost of education, housing, transportation, feeding, health, utilities etc.

- The least worker should be given an opportunity to aspire to the highest position through training and education.

- There should bereview of salaries of all public office holders geared towards cutting down some unreasonable entitlements or allowances. The Government should use the market realities to review minimum wage.

\section{Conclusion}

Minimum wage implementation did not bridge social inequality gap among workers. In as much as there was wage increases, the widened gap between the ministries, political office holders and civil servants did not allow the impacts of the wage to manifest conspicuously.

To ensure that the state achieve a significant freedom from inequality, there has to be a uniform salary for all the ministries and political office holders because the market forces are the same everywhere in the nation. In addition, the aforementioned recommendations are the necessary drivers to effectively bridge the inequality gap on implementation of minimum wage in the State.

\section{References}

i. Adegoke, Y. (2013) Disparity in income distribution in Nigeria. A lorenz curve and gini coefficient. Universal Journal of Management and Social Sciences, 3, pp. 16-28.

ii. Agba, M. Achimugu, C and Agboni, U. (2012) Reward system in the Nigerian political and public sector: The call for a paradigm shift in the 21st century.International Journal of Learning \& Development, 2, pp. 79-85 
iii. Agba, A. Ogaboh Ushie, E. (2013) Wage differentials and industrial disputes in Nigerian hospitals Journal of Business and Management,11, pp. 1-12.

iv. Ahiuma-Young, V. (2011) “The Long Road to N18,000 Minimum Wage”Retrievedfrom http/ / :www.vanguardngr.com/ 3011/ 02/ the-long-----18th July.

v. Akpansung, A. O. 2014). "An empirical assessment of the effects of minimum wage increases on unemployment during democratic governance in Nigeria" International Journal of Humanities and Social Sciences,4, pp. 87-98

vi. Asodike, J. and Atuwokiki, S. (2012) Civil servant perception on minimum wage increase in Nigeria. Global Journal of Human Social Science, 12(9), pp. 18-28.

vii. Cage, R. (1989) Spending Differences across Occupational Fields. Monthly Labour Review.December.

viii. Dabla-norris, E, Kochhar, K, Suphaphiphat, N. Ricka, F. and Tsounta, E. (2015) Causes and Consequences of Income Inequality: A Global Perspective. IMF.

ix. Eme, O. (2010) Trade Union and Employee Welfare in Nigeria: Implications of Minimum Wage on Industrial Relations Work and Productivity. In R. Onah and C. Oguonu (Eds), Readings in public administration. Nsukka: University of Nigeria press Ltd.

x. Emejuiwe1, V. (2017) Political office holders and income inequality in NigeriaRetrieved from http/ / www.guardian.ng/ opinion/ pol 27th march

xi. Emejuiwe2, V. (2017) Addressing income inequality in Nigeria.Retrieved from http/ / www.punching.com>addressingincome-inequality-in-nigeria.27th march

xii. Government of Imo State. (2011) New minimum wage for Imo State public servants. Establishment circular No 1/ 2011. Owerri: Office of the Head of Service. 1-17.

xiii. Government of Imo State. (2012) Implementation of the consolidated health salary structure (CONHESS) in Imo State public service HIS/ ESTSTR/ 46/ 111/T11/ 284.Owerri: Office of the Head of Service. P. 319-334.

xiv. Growing Gap between the Rich and the Poor (2017). https/ / www.boundless.com

xv. International Labour Office (2009) Minimum wage development,Geneva: Committee on employment and social policy.

xvi. Izueke, E. (2014). Theoretical framework of analyses in public administration. In 0. Ikeanyibe and P. Mbah (Eds), An anthology of theories for social research. (159-183). Enugu: University of Nigeria Press Ltd.

xvii. Makridis, C. (2016). Raising the minimum wage won't reduce inequality. Retrieved from http/ / www.newrepublic.com>article>y5th February

xviii. Mishel, L. (2014). The tight link between the minimum wage and wage inequality Retrieved from http/ / www.epi.org>blog.

xix. Okonjo-Iwuala in Idike, A (2014) Rising inequality and the challenge of change in Nigeria. International Journal of Humanities and Social Sciences, 4, pp. 207-213

xx. Pennington, R. (1999) Economics New York: Holt Rinehart and Winston Ltd.

xxi. Runsewe, O. (2017). Nigeria's lack of commitment to eradicating inequality isn't surprising. http/ / www.venturesafrica.com. 21st July.

xxii. Sobowale, D. (2000, May 14) Minimum wage and its consequences Vanguard, p.11.

xxiii. Stanlake, G. and Grant, S. (1999) Introductory economics. Singapore: Longman Ltd.

xxiv. Thomas, G. (2000) Consumer economic issues in America. U.S.A: Thomas Learning Custom Publishing.

xxv. Ubong, B. (2013) Social inequality, moral implications and questions for public policy. Journal of Educational and Social Research, 3, pp. 61- 71

xxvi. Chukwueke, E. (2010) Inequality in Nigeria: Open letter to all presidential candidates 2011. http/ / www.2011openletter.blog.com>2010>10

xxvii. Afonso, H, Lafleur, M, and Alarcon, D. (2015) Development strategy and policy analysis unit, development policy and analysis division. Department of economic and social affairs. http//www.un/ org/wess >dsp-policy01en/ development/ desa/ policy Development 1,21st October 